https://dx.doi.org/10.4314/ijs.v23i2.12

Ife Journal of Science vol. 23, no. 2 (2021)

\title{
EFFECT OF METHANOL EXTRACT OF Anacardium occidentale STEM BARK ON AGONIST-INDUCED CONTRACTION IN RAT UTERINE MUSCLE
}

\author{
Omolaso, B. O. \\ Department of Physiology, Faculty of Basic Medical Sciences, University of Medical Sciences, Ondo City, Ondo State, \\ Nigeria. E-mail: bomolaso@unimed.edu.ng. Tel.: +2347060471670 \\ (Revision received: $17^{\text {th }}$ February, 2021; Accepted: $20^{\text {th }}$ March, 2021)
}

\section{ABSTRACT}

\begin{abstract}
Anacardium occidentale (Ao) is widely used in ethnomedicine and the effect on contractility of the gut and heart muscles of laboratory rodents have been established however, its effect on the contractility of uterine muscle has been rarely researched. The present study investigated the effect of stem bark methanolic extract of Anacardium occidentale (AoME) on Isolated Rat Uterus Strips (IRUS). The Anacardium occidentale methanol extract (AoME) was obtained by solvent extraction. The IRUS were suspended in a bath containing $15 \mathrm{ml}$ of De Jalon's solution through a silk connected to a force transducer. A tension of $1.0 \mathrm{~g}$ was applied. The strips were allowed to equilibrate for a period of 60-90 min before the commencement of the experiment. The extract $(0.025-$ $0.3 \mathrm{mg} / \mathrm{ml}$ ) added cumulatively did not modify the normal tonus in most of the IRUS used except in one where it feebly contracted it. However, the contractile responses induced by acetylcholine $\left(10^{-9}-10^{-5} \mathrm{M}\right)$ and oxytocin $\left(10^{-9}-\right.$ $10^{-5} \mathrm{M}$ ) on the IRUS were almost completely blocked by pre-incubated AoME at a concentration of $0.2 \mathrm{mg} / \mathrm{ml}$. Stem bark methanol extract of Anacardium occidentale shifted the log concentration curve of both agonists to the right. The present results report the antagonistic effects of stem bark methanol extract of Anacardium occidentale on oxytocin and acetylcholine-induced contraction in rat uterus strips.
\end{abstract}

Keywords: Anacardium occidentale, Oxytocin, Acetylcholine, Uterus, Smooth muscle

\section{INTRODUCTION}

The use of herbs in management of diseases is an age-long practice. In Nigeria, there is a huge patronage of these herbal remedies despite paucity of information on their efficacy, contraindication, side effect and mechanisms of action. Anacardium occidentale is generally regarded in folk lore system of medicine in tropical countries as a medicinal plant. It is popularly known as cashew. Extract obtained from its various part such as the leaves, stem, bark, kernel, flowers, fruits and roots are used in the management of various diseases such as diarrhea, colic, toothache, diabetes, skin diseases, inflammation, hypotension, infertility, impotence (Leslie, 2005; Orwa, et al., 2009; Omoboyowa et al., 2013) Several scientific studies have been carried out to validate the anti-inflammatory (Olajide et al., 2004), genotoxicity (Barcelos, 2007), hypoglycemic (Alexander, 2008), antimicrobial (Ayepola and Ishola 2009), antioxidant (Chaves, et al., 2010), hypolipidemic (Elekofehinti, et al., 2016) and antidiarrheal (Omolaso, et al., 2018) effects of the plant. These studies were necessary since the rationale for the use of herbal medicine largely depends on folklore with little or no scientific evidence on efficacy and safety (Zhu et al., 2002). In addition, a general screening of herbal extract on the entire body system is usually required considering the fact that a drug that is indicated for treatment of a particular ailment could produce either a desirable or undesirable effects on other body systems aside its primary treatment target. The biological activities of Anacardium occidentale extracts on the gastrointestinal and cardiovascular systems are well reported. The plant extract decreases the motility of the gut muscle (Omolaso et al., 2018) and inhibits the contractility of the heart muscle (Francis et al., 2011). However, there is dearth of scientific report on the effect of the extract on muscles from other regions of the body such as the blood vessels, reproductive and respiratory systems. The present study evaluated the effect of stem bark methanol extract of Anacardium occidentale on Isolated Rat Uterus strip (IRUS) preparations.

\section{MATERIALS AND METHODS \\ Plant Preparation and Extraction}

The stem bark of Anacardium occidentale was collected at Abeokuta, Ogun State. The plant was authenticated by MrEsimelekuai D.P.O., a staff of the Herbarium of the Department of Botany, University of Ibadan, Ibadan, Nigeria and given the herbarium no.: UIH-22599

The stem bark was dried under shade and 
pulverised. The pulverised sample obtained (500 g) was soaked in $10 \mathrm{~L}$ of absolute methanol for 72 hours. The extract was filtered and methanol was later removed from the resultant mixture with the aid of a rotatory evaporator under reduced pressure at $52{ }^{\circ} \mathrm{C}$. The solid sample of the extract obtained was kept in the refrigerator. The crude methanol extract was designated as AoME.

\section{Chemicals and Drugs}

Methanol, acetylcholine (SIGMA), oxytocin (injection Pfizer limited), potassium chloride; sodium bicarbonate, calcium chloride; sodium phosphate, sodium chloride, D-glucose, magnessium chloride and stilbesterol were of analytical grade.

\section{Preparation of Isolated Rat Uterus Strips (IRUS)}

Female adult Wistar albino rats (200-220 g) used for this study were procured from the Animal House, University of Ibadan, Nigeria. The rats were treated forty eight hours before the commencement of the experiment with stilbesterol $(1.0 \mathrm{mg} / \mathrm{kg}$ s.c.). Each rat was then sacrificed following a slight decapitation and the abdomen cut open to show the fallopian tubes (uterine horns). The horns were dissected in such a manner that adhering tissues were removed. About $2.0 \mathrm{~cm}$ strip of the horn was cut. This was later mounted in a tissue bath filled with De Jalon's solution $(15 \mathrm{ml})$ composed of $\mathrm{NaCl}, 90 \mathrm{~g} ; 10 \% \mathrm{KCl}$, $42 \mathrm{ml}$; D-Glucose, $15 \mathrm{~g}$; $\mathrm{NaHCO}_{3}, 21 \mathrm{~g}$; molar $\mathrm{CaCl}_{2}$, $2.7 \mathrm{ml}$; dissolved in $10 \mathrm{~L}$ of distilled water. The solution was maintained at $37^{\circ} \mathrm{C}$ and aerated with $95 \%$ oxygen / 5\% carbon dioxide mixture (Harquin et al., 2006). Ethical Approval was obtained from the University of Ibadan Animal care and use research committee (UIACUREC/18/00820)

\section{Tissue Mounting Procedure}

In all cases, the mounted tissues were suspended by a silk on a force transducer (model 7004; Ugo Basile, Varese, Italy) connected to a data capsule acquisition system (model 17,400) which captures and records tissue responses. An initial tension of $1.0 \mathrm{~g}$ was applied to all the IRUS. An equilibration period of 60-90 min was allowed before the start of the experiments. During this time, the physiological solution (De Jalon) was replaced every $15 \mathrm{~min}$ and passive tension of $1.0 \mathrm{~g}$ readjusted (Hussein and Babatunde, 2011).

\section{Protocol for Interaction of Stem Bark Methanol Extract of Anacardium occidentale with Standard Agonists}

A sub-maximal concentration of AoME (0.2 $\mathrm{mg} / \mathrm{ml}$ ) based on preliminary study was used for interaction with the agonists. Cumulative addition of graded concentration $\left(10^{-9}-10^{-5} \mathrm{M}\right)$ of the agonists (acetylcholine and oxytocin) to the bath containing the mounted IRUS was first carried out. The responses were recorded on the data capsule. After washed out, the IRUS was allowed to rest for thirty (30) minutes and pre-incubated with $0.2 \mathrm{mg} / \mathrm{ml}$ (after final bath concentration calculation) of the extract for 15 minutes before graded concentrations of the agonists were added to the bath cumulatively again. The responses were also recorded. This protocol was repeated on strips from two other animals. In all, tissues responses were measured in at least six independent experiments (Harquin et al., 2006).

\section{Statistical Analysis}

Tissue responses of the activity of agonists alone and the agonists in the presence of AoME were calculated as percentage of the maximum response. The percentage responses obtained were plotted against log concentration to obtain a log-concentration-response curve using Graph pad prism statistical software 5.01. The $\mathrm{EC}_{50}$ values were determined, compared and possible interactions deduced.

\section{RESULTS}

Effect of Acetylcholine on Rat Uterus Strip Preparations Pre-incubated with Methanol Stem Bark Extract of Anacardium occidentale

Contraction of IRUS by the graded concentration of acetylcholine (cholinergic agonist) (Figure 1) was blocked by AoME pre-incubation at a concentration of $0.2 \mathrm{mg} / \mathrm{ml}$ (Figure 2). This observation is demonstrated on the Log concentration - response curves. Stem bark methanol extract of Anacardium occidentale shifted the Log concentration of acetylcholine to the right (Figure 3). The $\mathrm{EC}_{50}$ value of acetylcholine deduced from curve was raised from $5.32 \times 10^{-9} \mathrm{M}$ to $6.50 \times 10^{-9} \mathrm{M}$ 
Effect of Oxytocin on Rat Uterus Strip Preparations Pre-incubated with Methanol Stem Bark Extract of Anacardium occidentale Contraction of IRUS by the graded concentration of oxytocin added cumulatively (Figure 4) was blocked by AoME pre-incubation at a concentration of $0.2 \mathrm{mg} / \mathrm{ml}$ (Figure 5) The $\mathrm{EC}_{50}$ value of oxytocin deduced from the graph was raised from $3.16 \times 10^{-9} \mathrm{M}$ to $3.52 \times 10^{-6} \mathrm{M}$ by AoME (Figure 6).

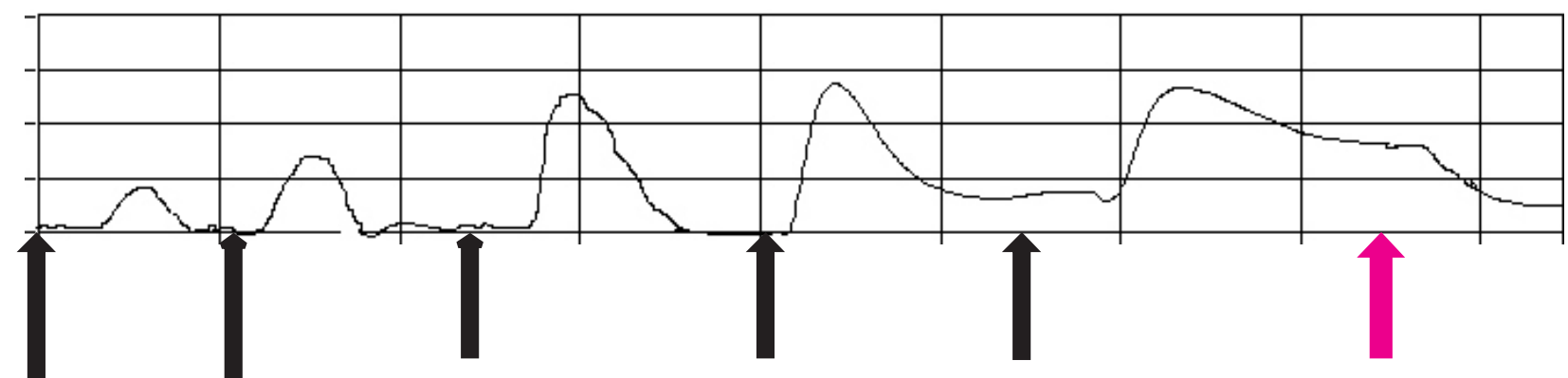

Figure 1: Typical Tracing showing the Contractile Effect of Graded Concentrations of Acetylcholine without Pre-incubation with AoME on Rat Uterus Strip

The black arrows represent point of cumulative addition of acetylcholine $\left(10^{-9}, 10^{-8}, 10^{-7}, 10^{-6}\right.$ and $\left.10^{-9} \mathrm{M}\right)$. The red arrow represent the washed out.

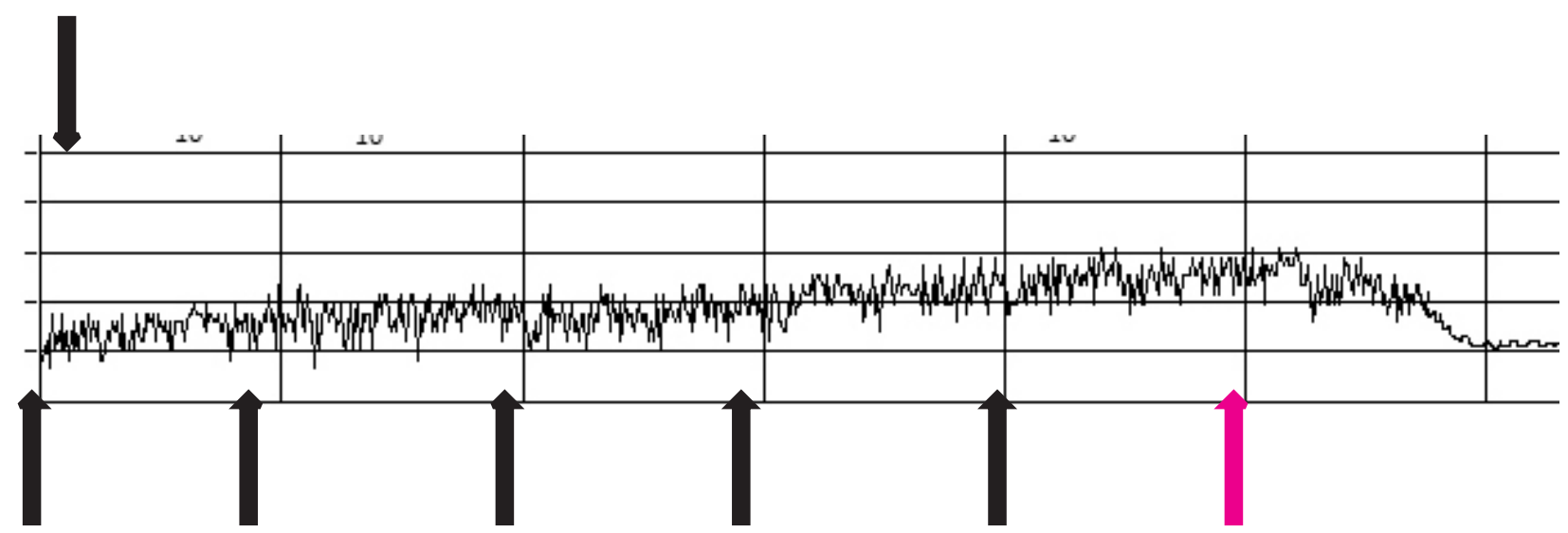

Figure 2: Typical Tracing showing the Contractile Effect of Graded Concentrations of Acetylcholine with Preincubation with AoME on Rat Uterus Strip

The blue arrow indicates the pre-incubation of the uterine strip with $0.2 \mathrm{mg} / \mathrm{ml}$ of AoME for $15 \mathrm{~min}$. The black arrows represent point of cumulative addition of acetylcholine $\left(10^{-9}, 10^{-8}, 10^{-7}, 10^{-6}\right.$ and $\left.10^{-5} \mathrm{M}\right)$. The red arrow represent the washed out

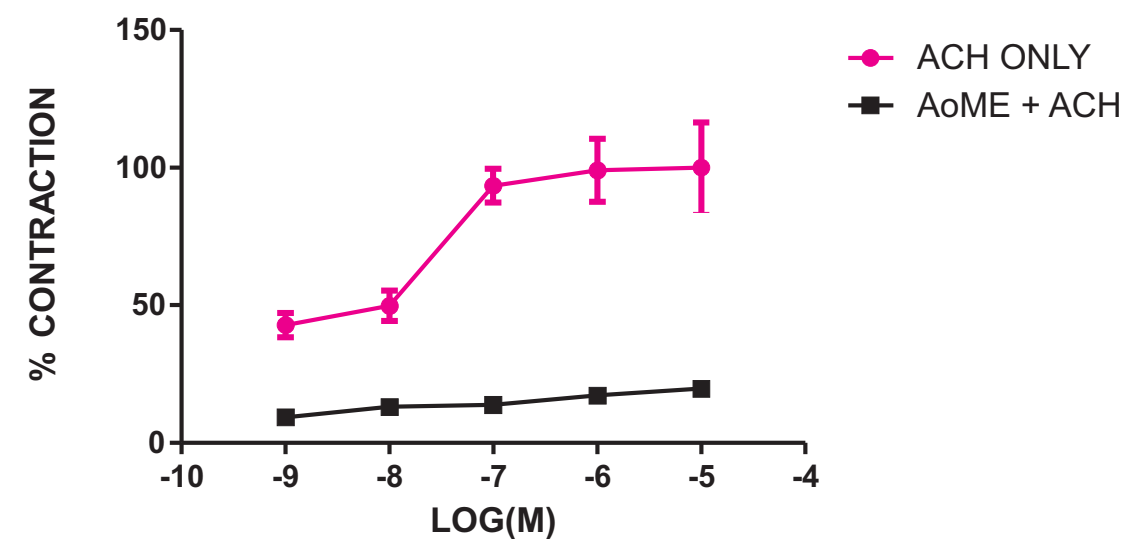

Figure 3: Concentration Response of Isolated Rat Uterus Strip to Cumulative Addition of Acetylcholine (ACH) in the absence (red circle) and presence of AoME $(0.2 \mathrm{mg} / \mathrm{ml}$, black square)

Each point represents Mean \pm SEM of six independent experiments. Log- concentration curve of acetylcholine is shifted to the right by AoME 


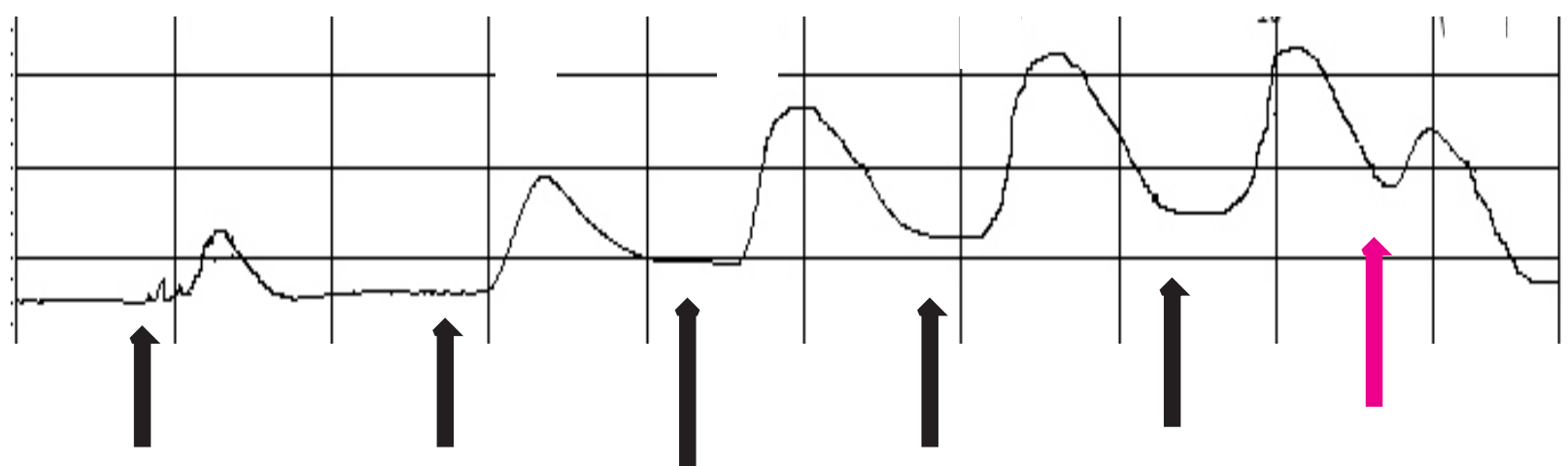

Figure 4: Typical Tracing showing the Contractile Effect of Graded Concentrations of Oxytocin alone on Rat Uterus Strip

The black arrows represent point of cumulative addition of acetylcholine $\left(10^{-9}, 10^{-8}, 10^{-7}, 10^{-6}\right.$ and $\left.10^{-9} \mathrm{M}\right)$. The red arrow represent the washed out.

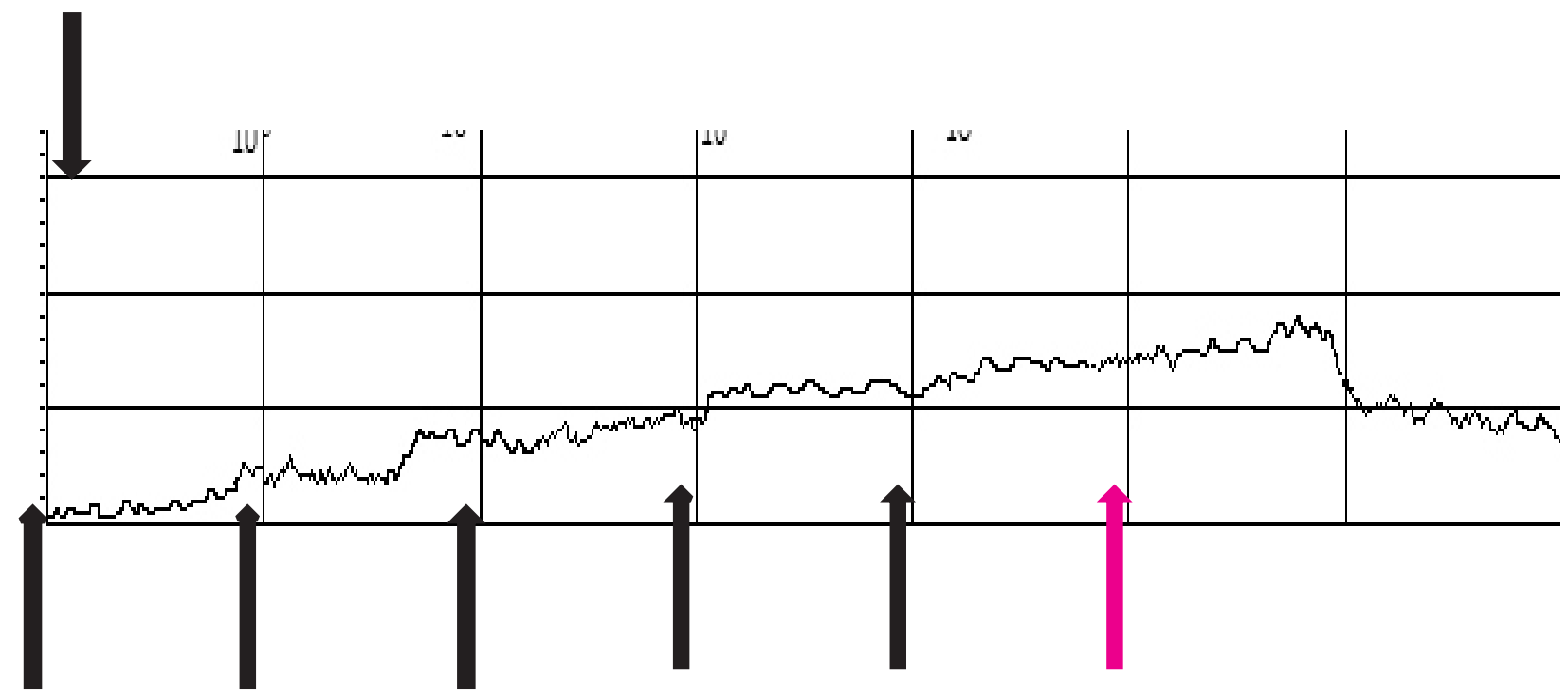

Figure 5: Typical Tracing showing the Contractile Effect of Graded Concentrations of Oxytocin with Preincubation with AoME on Rat Uterus Strip

The blue arrow indicates the pre-incubation of the uterine strip with $0.2 \mathrm{mg} / \mathrm{ml}$ of AoME for $15 \mathrm{~min}$. The Black arrows represent point of cumulative addition of acetylcholine $\left(10^{-9}, 10^{-8}, 10^{-7}, 10^{-6}\right.$ and $\left.10^{-9} \mathrm{M}\right)$. The red arrow represent the washed out.

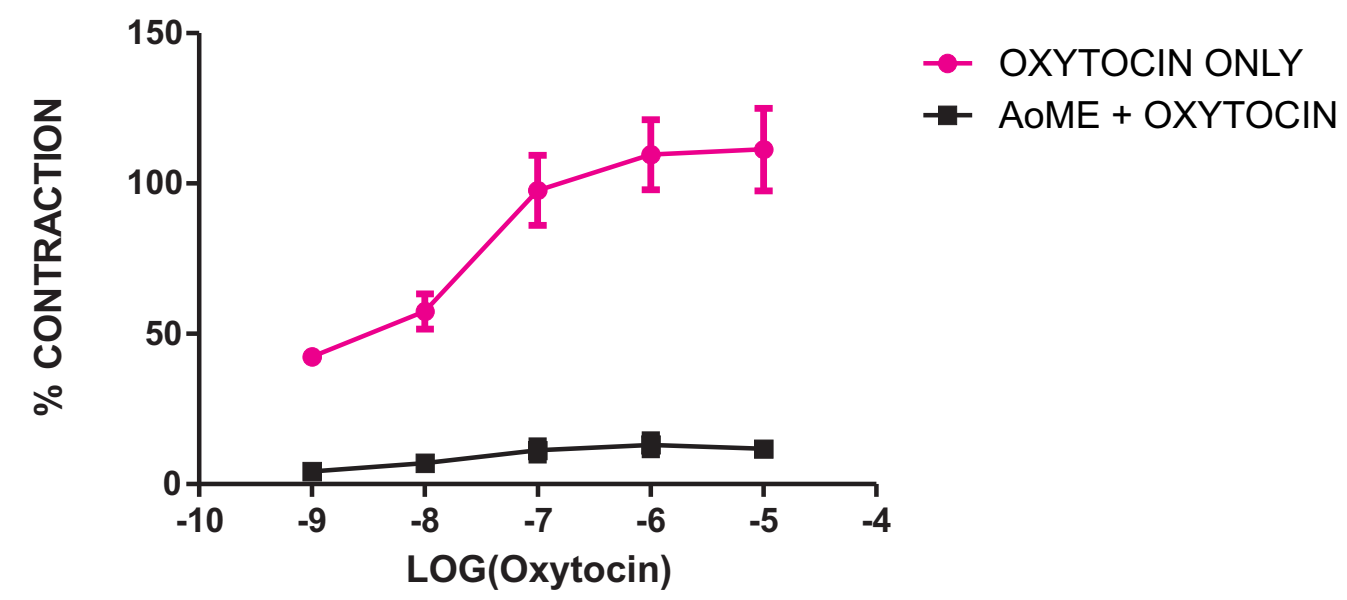

Figure 6: Concentration response of Isolated Rat Uterus Strips to Cumulative addition of Oxytocin in the absence (red circle) and presence of AoME $(0.2 \mathrm{mg} / \mathrm{ml}$, black square)

Each point represents Mean \pm SEM of six independent experiments. Log- concentration curve of oxytocin is shifted to the right by AoME. 


\section{DISCUSSION}

The present study reported the inhibitory effect of the stem bark extract of Anacardium occidentale on acetylcholine and oxytocin induced contraction in stilbesterol pre-treated uterine rat muscle. The pre-incubated AoME inhibited contractile responses evoked by acetylcholine and oxytocin when added cumulatively. This result was further supported by the shift of the Log concentration-response curves of both agonists to the right by the extract. The observed inhibitory action of Anacardium occidentale in the rat uterus is consistent with previous reports on the gut (Omolaso et al., 2018) and heart muscle (Francis et al., 2011) of rats. Uterine activity is regulated by complex and mutual interactions among sex steroids, neurohypophysial hormones, and neurotransmitters such as acetylcholine.

There are also many uterotonic agents and intracellular effectors that are known to be crucial for efficient uterine smooth-muscle contraction, such as oxytocin (Ralf et al., 2009). It is a general knowledge that when acetylcholine and oxytocin are dropped into a bathing medium containing uterine muscle, they evoke contractile responses. Oxytocin and acetylcholine initiate uterine contraction through binding to specific oxytocin and muscarinic receptors respectively (Williams, 2005; Ralf et al., 2009). It therefore implies that the observed inhibitory effect of the extract in rat uterine muscle may be via blockage of muscarinic and oxytocin receptors. It is not surprising to see such nonspecific antagonistic effect of herbal extracts. Aqueous extract of Acanthus monathus inhibited the contractions induced by PGF $2 \alpha$, acetylcholine, oxytocin, serotonin, histamine and calcium chloride in rat uterus (Harquin et al., 2006). When a plant extract exhibit non-receptor specificity being able to inhibit contraction evoked by more than one uterotonic agents, there is a possibility that a downstream mechanisms beyond and common to receptor site could be linked to the extract observed activity (Mukai et al., 1981).

For oxytocin and acetylcholine, increased intracellular calcium level seems to be a common downstream mechanism required for initiation of muscle contraction. Acetylcholine binding to muscarinic receptors initiates the opening of voltage- dependent calcium channels leading to calcium ions entry into the cell and the release of calcium from internal source (Bolton, 1979), while oxytocin stimulates increase in frequency and force of contraction through influx of calcium ions and intracellular release of calcium ions (Ebeigbe, 1982). Therefore, the observed inhibitory effect of the stem bark extract of Anacardium occidentale on contractile response evoked by acetylcholine and oxytocin could be attributed to the modulation of calcium channels in uterus leading to blockage of the entry of calcium from internal and external sources.

\section{RECOMMENDATION}

Considering the role of oxytocin in parturition, the observed antagonistic effects of this extract on uterine strip is undesired for prompt and safe child delivery. The use of extract should therefore be discouraged in women that are close to full term pregnancy. Contrarily, its use will be desired in women with threatened abortion.

\section{REFERENCES}

Alexander, H.T. (2008). A nutty chemical. Chemical and Engineering News, 86 (36): 26-2.

Ayepola, O.O. and Ishola, R.O. (2009). Evaluation of antimicrobial activity of Anacardium occidentale (linn) Advance in Medical and Dental Sciences, 3(1): 1-3.

Barcelos, G.R., Shimabukuro, F., Maciel, M.A. and Cólus, I.M. (2007). Genotoxicity and antigenotoxicity of cashew (Anacardium occidentale L.) in V79 cells. Toxicology in Vitro, 21(8): 1468-1475.

Bolton, T.B. (1979). Mechanisms of action of transmitters and other substances on smooth muscle Physiology Review, 59: 606-718.

Chaves, M.H., Lopes, A.M.G.C., Arimathea, L.J.D., Costa, D.A., Oliveira, C.A.A.O., Costa, A.F. and Brito, F.M.E. (2010). Total phenolics, antioxidant activity and chemical constituents of extracts of Anacardium occidentale L .Anacardiaceae. Brazillian Journal of Pharmacognosy, 20: $1-10$.

Ebeigbe, A.B. (1982). Calcium pools for Noradrenaline and potassium induced contraction of rat portal vein. Canadian Journal of Physiology and Pharmacolology, 60: 1225-1227. 
Elekofehinti, O.O., Osehodion, R.O., Adeyelu, T.T., Ogunwa, T.H., Olatunde, I., Aiwuyo, O. and Ejelonu, O.C. (2016). Hypoglycemic, hypolipidemic and antioxidant potentials of aqueous and ethanolic leaf extracts of Anacardium occidentale in alloxan induced type I diabetic rat model. British Journal of Medicine \& Medical Research, 14(12): 1-10.

Francis, O. T., Guy B.B., Gisèle, K., Jacques, Y. D., Paul A. Y., Noel, G. Z., and Michael, A. (2011). Anacardium occidentale Linn. (Anacardiaceae) Stem bark extract induces hypotensive and cardio-inhibitory effects in experimental animal models. African Journal of Traditional Complementary and Alternative Medicine, 8(4): 452-461.

Harquin, S. F., Emmanuel, A.A., Paulin, N., Gabriel, N. F. and Pierre, K.(2006). Tocolytic effect of Acanthus montanus in rat uterus. Pharmacologyonline, 3:9-17.

Hussein, M. S. and Babatunde, A.M. (2011). Vasorelaxant effects of aqueous leaf extract of Tridax procumbens on aortic smooth muscle isolated from the rats. Journal of Smooth Muscle Research, 48(2\&3): $37-45$.

Leslie, T. (2005). The healing power of rainforest herbs. Raintree nutrition, Square One Publishers, Inc. Carson City.

Mukai, T., Yamaguchi E., Goto, J. and Takagi, K. (1981). Smooth muscle relaxing drugs and guinea pig ileum. Journal of Pharmacology, 31:147-57.

Olajide, O.A., Aderogba, M. A., Aduragbenro, D.A. and Janet, M. M. (2004). Effects of Anacardium occidentale stem bark extract on in vivo inflammatory models. Journal of Ethnopharmacology, 95(2-3):139-42.

Omoboyowa, D.A., Nwodo, F.C. and Joshua, P.E. (2013). Antidiahoeal activity of chloroform ethanol extracts of cashew (Anacardium occidentale) Kernels. Journal of NaturalProducts, 6:109-117.

Omolaso, B.O., Oluwole, F.S. and Ajayi, M.A. (2018). Antidiarrhoeal property of the methanol extract of Anacardium occidentale Linn stem bark in laboratory rodents. International Journal of Basic, Applied and Innovative Research, 7(4): $151-160$.

Orwa, C., Mutua, A., Kindt, R., Jamnadass, R. and Simons, A. (2009). Agroforest database: A tree reference and selection guide version 4.0 (http: / / w w w.worldagro forestry.org/af/treedb/)

Ralf, D., Andreas, M., Patricia, G. O., Inge, H., Matthias, W. B. and Theodoros, M. (2009). Differences in muscarinic-receptor agonist-, oxytocin-, and prostaglandininduced uterine contractions. Fertility and Sterility, 92(5):1694-700.

Williams, T. G., (2005). Signal-transduction pathways that regulate visceral smooth muscle function coupling of muscarinic receptors to signaling kinases and effector proteins in gastrointestinal smooth muscles American Journal of Physiology gastrointestinal and Liver Physiology, 288: 849-853.

Zhu, M., Lew, K.T, Leung P (2002). Protective effects of plant formula on ethanolinduced gastric lesions in rats. Phytotheraphy Research,16:276-280. 